\title{
Molecular determinants of a competent bovine corpus luteum: first- vs final-wave dominant follicles
}

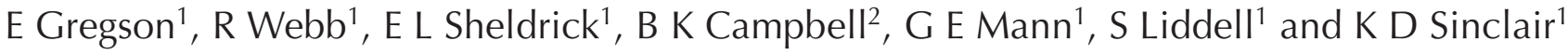 \\ ${ }^{1}$ School of Biosciences, University of Nottingham, Loughborough, UK and ${ }^{2}$ School of Clinical Sciences, \\ University of Nottingham, Nottingham, UK
}

Correspondence should be addressed to K D Sinclair; Email: kevin.sinclair@nottingham.ac.uk

\begin{abstract}
Reproductive management in cattle requires the synchrony of follicle development and oestrus before insemination. However, ovulation of follicles that have not undergone normal physiological maturation can lead to suboptimal luteal function. Here, we investigated the expression of a targeted set of 47 genes in (a) a first-wave vs final-wave dominant follicle (DF; the latter destined to ovulate spontaneously) and (b) 6-day-old corpora lutea (CLs) following either spontaneous ovulation or induced ovulation of a first-wave DF to ascertain their functional significance for competent CL development. Both the mass and progesterone-synthesising capacity of a CL formed following induced ovulation of a first-wave DF were impaired. These impaired CLs had reduced expression of steroidogenic enzymes (e.g. STAR and HSD3B1), luteotrophic receptors (LHCGR) and angiogenic regulators (e.g. VEGFA) and increased expression of BMP2 (linked to luteolysis). Relative to final-wave DFs, characteristic features of first-wave DFs included reduced oestradiol concentrations and a reduced oestradiol:progesterone ratio in the face of increased expression of key steroidogenic enzymes (i.e. CYP11A1, HSD3B1 and CYP19A1) in granulosa cells and reduced expression of the HDL receptor SCARB1 in thecal cells. Transcripts for further components of the TGF and IGF systems (e.g. INHA, INHBA, IGF2R and IGFBP2) varied between the first- and final-wave DFs. These results highlight the importance of hormones such as progesterone interacting with local components of both the TGF and IGF systems to affect the maturation of the ovulatory follicle and functional competency of the subsequent $\mathrm{CL}$.

Reproduction (2016) 151 563-575
\end{abstract}

\section{Introduction}

Since the introduction of ovulation synchronisation into mainstream reproductive management of cattle (Pursley et al. 1995), a plethora of studies have examined in detail the benefits of follicle synchrony in reproductive management programs (Bisinotto et al. 2014, Wiltbank \& Pursley, 2014). However, it has been shown that ovulation of follicles that have not undergone normal physiological maturation can lead to suboptimal luteal function compared with spontaneous ovulation. For example, following synchronisation, Perry et al. (2005) found that ovulation of smaller follicles (presumed to be short of full maturity) resulted in decreased pregnancy rates. This was associated with lower oestradiol (E2) on the day of insemination together with impaired subsequent luteal function. In contrast, they reported no effect of ovulatory follicle size when ovulation occurred spontaneously. Furthermore, Bisinotto et al. (2010) found differences in pregnancy rate following artificial insemination (Al) according to wave of the ovulated follicle, with higher pregnancy rates following ovulation of a second- than a first-wave dominant follicle (DF). However, less is known about the impact of ovulatory control programs on the detailed molecular control mechanisms underpinning the adequacy of the ovulatory follicle and resulting corpus luteum $(\mathrm{CL})$.

The expression of several genes involved with ovulation, luteinisation and $\mathrm{CL}$ function is under endocrine control. Production of the prostaglandin $\mathrm{PGF}_{2 \alpha^{\prime}}$ for instance, has been shown to be regulated by progesterone (P4) (Skarzynski \& Okuda, 1999, Okuda et al. 2004). A first-wave DF undergoes selection during a period of low circulating P4, whereas, during later follicular waves, DF selection occurs during the luteal phase of the oestrous cycle in the presence of higher concentrations of circulating P4 (Savio et al. 1988, Ginther et al. 1989). There is evidence that P4 supplementation before induced ovulation (around the time of ovulatory DF selection) can increase pregnancy per Al (Wiltbank et al. 2011, Colazo et al. 2013), which is likely due to the beneficial effects of $\mathrm{P} 4$ supplementation on the development of the first-wave DF (Bisinotto et al. 2010). 
Table 1 Transcripts quantified in bovine dominant follicles and corpora lutea by GeXP.

\begin{tabular}{|c|c|c|c|}
\hline Gene & Full name & Accession No. & Primers \\
\hline \multicolumn{4}{|c|}{ TGF- $\beta$ superfamily } \\
\hline$A M H$ & Anti-Mullerian hormone & NM_173890 & $\begin{array}{l}\text { F: aggtgacactatagaatacgtgagctgagcgtagacct } \\
\text { R: gtacgactcactatagggagacaggctgatgaggagctt }\end{array}$ \\
\hline$B M P 2$ & Bone morphogenetic protein (BMP) 2 & NM_001099141 & $\begin{array}{l}\text { F: aggtgacactatagaataacttttggacaccaggttgg } \\
\text { R: gtacgactcactatagggactaatccgcacatgcctctt }\end{array}$ \\
\hline$B M P 4$ & BMP4 & NM_001045877 & $\begin{array}{l}\text { F: aggtgacactatagaatagcttccaccacgaagaacat } \\
\text { R: gtacgactcactatagggatagtcgtgtgatgaggtgcc }\end{array}$ \\
\hline BMP6 & BMP6 & XM_869844.3 & $\begin{array}{l}\text { F: aggtgacactatagaatatgtcatgtgggcattttgtt } \\
\text { R: gtacgactcactatagggaaccaacacaggagaagtggc }\end{array}$ \\
\hline$B M P R 1 A$ & BMP receptor, type IA & NM_001076800 & $\begin{array}{l}\text { F: aggtgacactatagaatagtgtgtgtgtgcatacgtgc } \\
\text { R: gtacgactcactatagggaaatggcttttatgcgattgg }\end{array}$ \\
\hline$B M P R 1 B$ & BMP receptor, type IB & NM_001105328 & $\begin{array}{l}\text { F: aggtgacactatagaataatggaacagcagaggaatgc } \\
\text { R: gtacgactcactatagggaaagtgccacggagaagaaaa }\end{array}$ \\
\hline$B M P R 2$ & BMP receptor, type II & XM_617592 & $\begin{array}{l}\text { F: aggtgacactatagaatacctgtcacacaataggcgtg } \\
\text { R: gtacgactcactatagggactggacatcgaatgctcaga }\end{array}$ \\
\hline INHA & Inhibin, alpha & NM_174094 & $\begin{array}{l}\text { F: aggtgacactatagaatatagtgcaccctcccagtttc } \\
\text { R: gtacgactcactatagggaggttgggcaccatctcatac }\end{array}$ \\
\hline INHBA & Inhibin, beta A & NM_174363 & $\begin{array}{l}\text { F: aggtgacactatagaataccaaagaaggcagtgacctg } \\
\text { R: gtacgactcactatagggaagctggagacagggaagatg }\end{array}$ \\
\hline INHBB & Inhibin, beta B & NM_176852 & $\begin{array}{l}\text { F: aggtgacactatagaataagatcatcagcttcgccg } \\
\text { R: gtacgactcactatagggacttcaggtagagccacaggc }\end{array}$ \\
\hline \multicolumn{4}{|c|}{ Insulin/IGF family } \\
\hline IGF1 & Insulin-like growth factor (IGF) 1 & NM_001077828 & $\begin{array}{l}\text { F: aggtgacactatagaatagaagatgcccatcacatcct } \\
\text { R: gtacgactcactatagggagcctcctcagatcacagctc }\end{array}$ \\
\hline$I G F 1 R$ & IGF1 receptor & XM_606794.3 & $\begin{array}{l}\text { F: aggtgacactatagaatacaaaggcaatctgctcatca } \\
\text { R: gtacgactcactatagggaagttcccctctagctgctcc }\end{array}$ \\
\hline IGF2 & IGF2 & NM_174087 & $\begin{array}{l}\text { F: aggtgacactatagaataacagcgagacacttgcagaa } \\
\text { R: gtacgactcactatagggagacggtggtgactctgtgtg }\end{array}$ \\
\hline$I G F 2 R$ & IGF2 receptor & NM_174352 & $\begin{array}{l}\text { F: aggtgacactatagaataggaccttctacctgagcgtg } \\
\text { R: gtacgactcactatagggagttctggagctgaaaggtcg }\end{array}$ \\
\hline IGFBP2 & IGF binding protein 2 & NM_174555 & $\begin{array}{l}\text { F: aggtgacactatagaatacaagggtggcaaacatcac } \\
\text { R: gtacgactcactatagggagaggttgtacaggccatgct }\end{array}$ \\
\hline IGFBP4 & IGF binding protein 4 & NM_174557 & $\begin{array}{l}\text { F: aggtgacactatagaatacaggctcccctttactcctc } \\
\text { R: gtacgactcactatagggacctttctccatcaggcacat }\end{array}$ \\
\hline IGFBP5 & IGF binding protein 5 & NM_001105327.1 & $\begin{array}{l}\text { F: aggtgacactatagaatagatcgaaagagactcccgtg } \\
\text { R: gtacgactcactatagggagtcagcttctttctgcggtc }\end{array}$ \\
\hline INSR & Insulin receptor & XM_590552 & $\begin{array}{l}\text { F: aggtgacactatagaataaaagaggccccttaccagaa } \\
\text { R: gtacgactcactatagggatgtacggcgttcatcagaaa }\end{array}$ \\
\hline \multicolumn{4}{|c|}{ Steroidogenic mediators } \\
\hline CYP11A1 & $\begin{array}{l}\text { Cytochrome } \mathrm{P} 450, \text { family } 11 \\
\text { subfamily A, polypeptide } 1\end{array}$ & NM_176644.2 & $\begin{array}{l}\text { F: aggtgacactatagaataaagtttgacccaaccaggtg } \\
\text { R: gtacgactcactatagggagtgtccacgtcaccgatatg }\end{array}$ \\
\hline CYP17A1 & $\begin{array}{l}\text { Cytochrome } \mathrm{P} 450 \text {, family } 17, \\
\text { subfamily A, polypeptide } 1\end{array}$ & NM_174304 & F: aggtgacactatagaataagacaaccaaaagggcattg \\
\hline CYP19A1 & $\begin{array}{l}\text { Cytochrome } \mathrm{P} 450, \text { family } 19 \\
\text { subfamily A, polypeptide } 1\end{array}$ & NM_174305 & F: aggtgacactatagaataaagccaagagcaacaagcat \\
\hline ESR1 & Oestrogen receptor 1 & NM_001001443 & $\begin{array}{l}\text { R: gtacgactcactatagggaatttggcgctaattccaaga } \\
\text { F: aggtgacactatagaataggtgtacatggacagcagca } \\
\text { R: gtacgactcactatagggatccaggtaatagggcacctg }\end{array}$ \\
\hline ESR2 & Oestrogen receptor 2 & NM_174051 & $\begin{array}{l}\text { F: aggtgacactatagaatagacagaccacaagcccaaat } \\
\text { R: gtacgactcactatagggagttcacgccaaggactctt }\end{array}$ \\
\hline HSD3B1 & $\begin{array}{l}\text { Hydroxyl-delta-5-steroid } \\
\text { dehydrogenase, } 3 \text { beta- and steroid } \\
\text { delta-isomerase } 1\end{array}$ & NM_174343.2 & F: aggtgacactatagaatagcagaaaaccaaggagtgga \\
\hline$P G R$ & Progesterone receptor & XM_583951.4 & $\begin{array}{l}\text { R: gtacgactcactatagggaatcaccttgtctgtcccctg } \\
\text { F: aggtgacactatagaatagttctcgctctacggggac } \\
\text { R: gtacgactcactatagggattgtacaggacgcactccag }\end{array}$ \\
\hline SCARB 1 & $\begin{array}{l}\text { Scavenger receptor class B, } \\
\text { member } 1\end{array}$ & NM_174597.2 & $\begin{array}{l}\text { F: aggtgacactatagaataacaaactgggaacatccagc } \\
\text { R: gtacgactcactatagggagatggggatgagcagtagga }\end{array}$ \\
\hline$\angle R P 8$ & $\begin{array}{l}\text { Low-density lipoprotein receptor- } \\
\text { related protein } 8\end{array}$ & NM_001097565.1 & $\begin{array}{l}\text { R: gtacgactcactatagggagatggggatgagcagtagga } \\
\text { F: aggtgacactatagaataccctgcaagggttcatgtat }\end{array}$ \\
\hline SHBG & Sex hormone-binding globulin & NM_001098858 & $\begin{array}{l}\text { R: gtacgactcactatagggagaaaatggcctcattctcca } \\
\text { F: aggtgacactatagaatacccagagtcattggaggcta } \\
\text { R: gtacgactcactatagggagatcccaagtccgaaactca }\end{array}$ \\
\hline STAR & Steroidogenic acute regulatory protein & NM_174189.2 & $\begin{array}{l}\text { F: aggtgacactatagaatacctactgccaggaaagatgc } \\
\text { R: gtacgactcactatagggaagaacctaggagagagccgc }\end{array}$ \\
\hline
\end{tabular}


Table 1 (Continued).

\begin{tabular}{|c|c|c|c|}
\hline Gene & Full name & Accession No. & Primers \\
\hline \multicolumn{4}{|l|}{ Cytokines } \\
\hline IL1B & Interleukin (IL) 1 , beta & NM_174093.1 & $\begin{array}{l}\text { F: aggtgacactatagaatatgaacccatcaacgaaatga } \\
\text { R: gtacgactcactatagggatggatgtttccatctcccat }\end{array}$ \\
\hline IL2 & IL2 & NM_180997.1 & $\begin{array}{l}\text { F: aggtgacactatagaatacaaacggtgcacctacttca } \\
\text { R: gtacgactcactatagggagaatccttgatctctctgggg }\end{array}$ \\
\hline IL6 & IL6 & NM_173923.2 & $\begin{array}{l}\text { F: aggtgacactatagaataagctctcattaagcgcatgg } \\
\text { R: gtacgactcactatagggatctgcgatctttgcttcag }\end{array}$ \\
\hline IL8 & IL8 & NM_173925 & $\begin{array}{l}\text { F: aggtgacactatagaataaccaatggaaacgaggtctg } \\
\text { R: gtacgactcactatagggacctacaccagacccacacag }\end{array}$ \\
\hline KITLG & KIT ligand & NM_174375 & $\begin{array}{l}\text { F: aggtgacactatagaataagcattgccagcattctttt } \\
\text { R: gtacgactcactatagggagaactgttacccgccaatgt }\end{array}$ \\
\hline MIF & $\begin{array}{l}\text { Macrophage migration inhibitory } \\
\text { factor }\end{array}$ & NM_001033608.1 & F: aggtgacactatagaatacaacttctgcgacatgaacg \\
\hline PTPRC & $\begin{array}{l}\text { Protein tyrosine phosphatase } \\
\text { receptor type C }\end{array}$ & BC148881 & $\begin{array}{l}\text { R: gtacgactcactatagggacgtttattgctccttccagg } \\
\text { F: aggtgacactatagaatacggagatgcaggatcaaact }\end{array}$ \\
\hline & & & R: gtacgactcactatagggacccagatcatcctccagaaa \\
\hline \multicolumn{4}{|c|}{ Apoptotic regulators } \\
\hline CCND2 & Cyclin D2 & NM_001076372.1 & $\begin{array}{l}\text { F: aggtgacactatagaataagcagtaccgtcaggaccag } \\
\text { R: gtacgactcactatagggaagagaaggagagagcggattg }\end{array}$ \\
\hline CFLAR & $\begin{array}{l}\text { CASP8- and FADD-like apoptosis } \\
\text { regulator }\end{array}$ & NM_001012281.1 & F: aggtgacactatagaatactaaggctccagaatggcag \\
\hline GADD45B & $\begin{array}{l}\text { Growth arrest and DNA damage- } \\
\text { inducible, beta }\end{array}$ & NM_001040604.1 & $\begin{array}{l}\text { R: gtacgactcactatagggagcttgacttcatagcccagg } \\
\text { F: aggtgacactatagaatatcacgaaccctcacacagac }\end{array}$ \\
\hline \multicolumn{4}{|c|}{ Angiogenic regulators } \\
\hline HIF1A & $\begin{array}{l}\text { Hypoxia-inducible factor } 1 \text {, alpha } \\
\text { subunit }\end{array}$ & NM_174339.3 & F: aggtgacactatagaatatgcctctgaaactccaaagc \\
\hline VEGFA & Vascular endothelial growth factor A & NM_174216.1 & $\begin{array}{l}\text { R: gtacgactcactatagggactggggcatggtaaaagaaa } \\
\text { F: aggtgacactatagaataagcaaggcaagaaaatccct } \\
\text { R: gtacgactcactatagggatcctggtgagacgtctggtt }\end{array}$ \\
\hline \multicolumn{4}{|l|}{ Miscellaneous } \\
\hline FGF1 & Fibroblast growth factor 1 & NM_174055 & $\begin{array}{l}\text { F: aggtgacactatagaatagtaacgcgcttctaaatgcc } \\
\text { R: gtacgactcactatagggaatgagagggaatcatgccag }\end{array}$ \\
\hline FSHR & FSH receptor & NM_174061 & $\begin{array}{l}\text { F: aggtgacactatagaataatgttttccagggagcctct } \\
\text { R: gtacgactcactatagggatgacccctagcctgagtcat }\end{array}$ \\
\hline SRSF9 & Splicing factor, arginine/serine-rich 9 & NM_001083398 & $\begin{array}{l}\text { F: aggtgacactatagaataatatgccctgcgtaaactgg } \\
\text { R: gtacgactcactatagggaattcccaccacctgtctcag }\end{array}$ \\
\hline PTGFR & Prostaglandin F2 $\alpha$ receptor & BD187584 & $\begin{array}{l}\text { F: aggtgacactatagaatatgcccactttttctaggcag } \\
\text { R: gtacgactcactatagggaatggcattgcaaacaaatga }\end{array}$ \\
\hline \multicolumn{4}{|c|}{ House-keeping genes } \\
\hline GAPDH & $\begin{array}{l}\text { Glyceraldehyde-3-phosphate } \\
\text { dehydrogenase }\end{array}$ & NM_001034034 & F: aggtgacactatagaatacaccctcaagattgtcagca \\
\hline$H 2 A F Z$ & $\mathrm{H} 2 \mathrm{~A}$ histone family, member $\mathrm{Z}$ & NM_174809.2 & $\begin{array}{l}\text { R: gtacgactcactatagggaggtcataagtccctccacga } \\
\text { F: aggtgacactatagaatatccagtgttggtgattccag } \\
\text { R: gtacgactcactatagggatttggttggttggaaagctaa }\end{array}$ \\
\hline$R P L P O$ & Ribosomal protein, large, P0 & NM_001012682.1 & $\begin{array}{l}\text { F: aggtgacactatagaatacttgctgaaaaggtcaaggc } \\
\text { R: gtacgactcactatagggagactcctccgactcctcctt }\end{array}$ \\
\hline
\end{tabular}

With the foregoing discussion in mind, our hypothesis was that the hormonal milieu within which a DF develops affects its ability to form a viable $\mathrm{CL}$, that this is related to the expression of genes with key roles in regulating DF development, subsequent luteinisation and $C L$ function, and that the expression of these genes differs between the first- and final-wave DFs. It was also hypothesised that the $\mathrm{CL}$ formed following induced ovulation of a first-wave DF would be smaller and less capable of P4 production than those formed following spontaneous ovulation and that this would be associated with altered expression of genes involved in cellular differentiation, tissue growth and steroidogenesis.
To test these hypotheses, we conducted an experiment that involved 24 cyclic virgin heifers in which we compared the expression of a targeted set of genes (Table 1), with established physiological effects within the bovine ovary, in follicles and CLs of differing size at contrasting stages of the oestrous cycle. Specifically, we wanted to compare the molecular characteristics of (a) a first-wave DF to that of a final-wave DF destined to ovulate spontaneously and (b) a 6-day-old CL following spontaneous ovulation to a 6-day-old CL following induced ovulation of a first-wave DF. These data were related to quantitative measures of steroidogenesis and local and systemic growth factor and hormone concentrations. 


\section{Materials and methods}

\section{Sample collection}

A total of 24 post-pubertal Hereford $\times$ Holstein heifers (mean \pm S.E.M. live weight of $417.5 \pm 7.3 \mathrm{~kg}$ and a body condition score (BCS) of $2.53 \pm 0.05$ units; Lowman et al. (1976)) were allocated to one of the three treatment groups (A-C) according to live weight and BCS, giving eight animals per treatment group. Animals were group housed on straw bedding and given ad libitum access to water and hay. Mineralised concentrates were given twice daily at a rate of $5 \mathrm{~kg}$ per animal per day, rising to $6 \mathrm{~kg}$ as the animals gained weight in line with their metabolisable energy and protein requirements (AFRC 1993). All procedures were performed under the auspices of the Animal Scientific Procedures Act (1986) and approved by the University of Nottingham ethics review committee.

Oestrous cycles were synchronised initially using two intramuscular prostaglandin (PG) injections (2 mL Estrumate; Intervet UK Ltd., Milton Keynes, UK) given 11 days apart. An intramuscular injection of GNRH (2.5 mL Receptal; Intervet UK Ltd., Milton Keynes, UK) was given $48 \mathrm{~h}$ after the initial dose of PG (Fig. 1). Timing of ovulation was confirmed by transrectal real-time B-mode ultrasonography using an Aloka SSD-500v scanner (Aloka Co. Ltd., Tokyo, Japan) equipped with a $5 \mathrm{MHz}$ linear array on nominal day -1 and +1 of the anticipated day of ovulation. We (KD Sinclair and GE Mann, unpublished data) have previously observed that transrectal ovarian ultrasonography on the expected day of ovulation can delay or inhibit this event in some animals. Heifers in group A were killed on day 6 after synchronised ovulation (day 0) to recover a first-wave DF and a 6-day-old, spontaneous CL. Animals in group B were given $5 \mathrm{~mL}$ GNRH and $2 \mathrm{~mL}$ PG on day 6 to cause ovulation of the first-wave DF and regression of the spontaneous $\mathrm{CL}$, then killed on day 13 to retrieve a 6-dayold, induced CL and a DF. Animals in group $C$ were given $2 \mathrm{~mL}$ PG on day 18 and killed on day 19 to retrieve a final-wave DF and a regressing CL. All animals were blood sampled daily by jugular venipuncture and samples were analysed for plasma P4 and insulin-like growth factor 1 (IGF-1). Additional blood samples were taken from group $\mathrm{B}$ at 0,1 and $2 \mathrm{~h}$ after $\mathrm{GNRH}$ injection on day 6 for plasma LH analysis. To monitor ovarian follicular development and to confirm cyclicity, animals in group $\mathrm{C}$ underwent transrectal ultrasonography daily, except on the day of expected ovulation. All other animals underwent transrectal ultrasonography on the days before and following expected ovulations (including that following initial synchronisation; day 0) and on the day before killing.

Animals were blood sampled before transportation to an on-site abattoir for killing. Ovaries from each animal were recovered, transferred to the laboratory within $10 \mathrm{~min}$ of killing and processed immediately. The largest follicle ( $\geq 11 \mathrm{~mm}$ ) was dissected from each pair of ovaries. Follicular fluid was aspirated from this large follicle (presumed to be a DF), the largest subordinate follicle (SF) and a selection of smaller subordinate follicles $(2-6 \mathrm{~mm})$ from each pair of ovaries and stored at $-20^{\circ} \mathrm{C}$. Granulosa cells were then scraped from the DF and washed in PBS before storage at $-80^{\circ} \mathrm{C}$ in $\mathrm{RLT}+$ lysis buffer (Qiagen). The thecal sheet was then peeled away from the DF wall using a pair of fine forceps, washed in PBS and stored at $-80^{\circ} \mathrm{C}$ in $\mathrm{RLT}+$ lysis buffer (Qiagen).

CLs were dissected from ovaries, measured, weighed and then divided into three sections. The first section was minced using a scalpel blade, washed in PBS and then centrifuged at $1500 \mathrm{~g}$ for $3 \mathrm{~min}$. RLT+ lysis buffer (Qiagen) was added to the cell pellet, which was stored at $-80^{\circ} \mathrm{C}$ to be homogenised immediately before RNA extraction. The second section was minced and washed in PBS and then divided further to give three $25 \mathrm{mg}( \pm 2 \mathrm{mg})$ samples per animal, which were snap frozen in liquid nitrogen and stored at $-80^{\circ} \mathrm{C}$ before $\mathrm{P} 4$ analysis by ELISA. The third section was also minced, washed and divided to give three $25 \mathrm{mg}$ ( $\pm 2 \mathrm{mg}$ ) samples per animal. These samples were re-suspended in $2 \mathrm{~mL}$ culture medium (M199 containing $0.068 \mathrm{mM}$ L-glutamine) and incubated at $38^{\circ} \mathrm{C}$ for $30 \mathrm{~min}$ in a shaking water bath at 70 strokes perminute. They were then centrifuged at $1500 \mathrm{~g}$ for $5 \mathrm{~min}$ and the tissue and spent media were snap frozen separately in liquid nitrogen and stored at $-80^{\circ} \mathrm{C}$ before $\mathrm{P} 4$ analysis by ELISA.

\section{Hormone assays}

A commercially available ELISA kit (Ridgeway Science, St. Briavels, UK) was used to measure P4 in follicular fluid, blood plasma, spent culture media and $\mathrm{CL}$ extracts as described previously (Wonnacott et al. 2010). CL tissue samples were ethanol extracted before P4 assay. Double-distilled ethanol $(5 \mathrm{~mL})$ was added to each sample, on ice. The samples were homogenised for 30 s (Polytron PT400; Kinematica, Lucerne, Switzerland), evaporated to dryness using a speedvac (Savant DNA 110; Thermo Fisher Scientific) and then re-dissolved in $1 \mathrm{~mL}$ PBS. Plasma standards and quality controls (QCs) (Ridgeway Science, St. Briavels, UK) were used when analysing blood plasma samples, and buffer standards and QCs (Ridgeway Science, St. Briavels, UK) were used when analysing all other samples, with intra- and inter-assay coefficients of variation of 6.69 and $5.68 \%$ respectively.

Oestradiol was measured by radioimmunoassay, as described previously (Kanakkaparambil et al. 2009). The intraand inter-assay coefficients of variation for this assay were 4.63 and $11.63 \%$ respectively. A commercially available bovine ELISA kit (LH Detect; ReproPharm, Nouzilly, France) was used to measure LH in blood plasma. The intra- and inter-assay coefficients of variation for this assay were 5.49 and $15.24 \%$ respectively.

A commercially available kit was used to measure IGF1 in blood plasma (DRG Instruments GmbH, Marburg, Germany) from day 0 and the day of killing (refer to Fig. 1). No sample dilution was necessary. The intra- and inter-assay coefficients of variation for this assay were 4.43 and $7.21 \%$ respectively.

\section{Transcript expression}

RNA extraction was performed using a commercially available kit (RNeasy mini kit; Qiagen) and RNA concentration was determined using a NanoDrop ND-1000 UV-vis spectrophotometer (Thermo Fisher Scientific). Samples were diluted in RNase-free water to a concentration of $20 \mathrm{ng} / \mu \mathrm{L}$ before a further gDNA removal step using another 
A

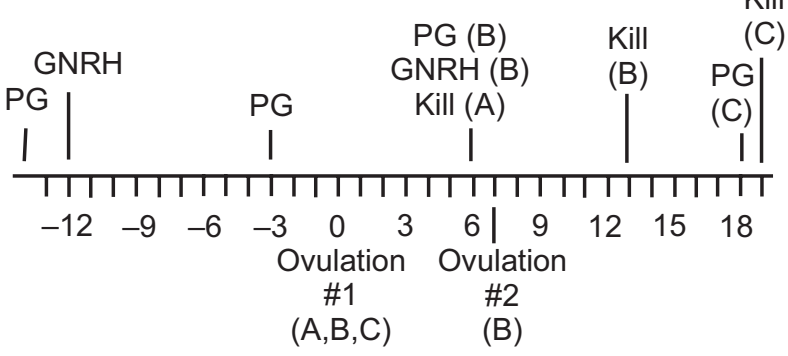

B

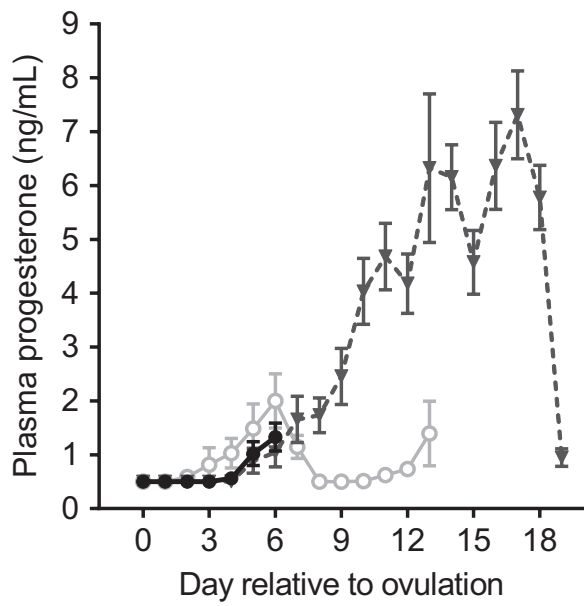

Figure 1 (A) Oestrous cycle manipulation timeline. Oestrous cycles of 24 Hereford $\times$ Holstein heifers were synchronised using prostaglandin (PG) and gonadotrophin-releasing hormone (GNRH). Animals were given further injections according to their treatment group, indicated by letters A-C in brackets. Group A animals were killed at day 6 to recover a first-wave dominant follicle (DF) and 6-day-old corpus luteum (CL); group B animals ovulated on day 7 and were killed on day 13 to recover a 6 -day-old induced $\mathrm{CL}$; group $\mathrm{C}$ animals were killed on day 19 to recover a final-wave DF. (B) Plasma progesterone was monitored from day 0 to killing for group A (closed circles), group B (open circles) and group C (triangles).

commercially available kit (TURBO DNA-free; Ambion). mRNA was denatured at $70^{\circ} \mathrm{C}$ for $10 \mathrm{~min}$ using a thermal cycler (BioRad) before RT and subsequent transcript expression analysis.

Expression of 47 genes (Tables 1 and 2) known to regulate DF and $\mathrm{CL}$ function was quantified using the GenomeLab GeXP Genetic Analysis System (Beckman Coulter Inc., High Wycombe, UK). This method utilises gene-specific primers that have a universal sequence tag. Forward universal primers within the PCR buffer are fluorescently labelled, allowing detection and quantification of up to 30 size-separated products within a single PCR (Wu et al. 2008, Rai et al. 2009). Transcripts were divided arbitrarily between two multiplex reactions. Due to the size and relative importance of the LHCGR transcript in ovulation and luteinisation, a separate multiplex reaction was designed to amplify several regions of the mRNA (Table 2).

RT-PCR were performed using reagents (including an internal standard) and software provided by Beckman Coulter Inc. (High Wycombe, UK). For each of the three different multiplex reactions, reverse primers (Sigma-Genosys Ltd., Poole, UK) were mixed together at concentrations ranging from 60 to $1500 \mathrm{nM}$ in $10 \mathrm{mM}$ Tris- $\mathrm{HCl}$ solution, $\mathrm{pH} 8.0$ (Sigma-Aldrich), and forward primers (Sigma-Genosys Ltd., Poole, UK) were mixed together at a concentration of $200 \mathrm{nM}$ each using the same solution. Reverse primer concentrations were adjusted to allow for variation in initial concentrations of mRNA templates and primer efficiencies. Forward primers contained universal sequence tags used for amplification after the first few cycles of PCR. For primer sequences (Tables 1 and 2). RT was carried out including the mixture of reverse primers, and 35 cycles of PCR were carried out including the mixture of forward primers, as per the manufacturer's instructions. The resulting PCR products were diluted 1:30 in water and $2 \mu \mathrm{L}$ diluted sample were mixed with $0.5 \mu \mathrm{L}$ DNA size standard-400 and $37.5 \mu \mathrm{L}$ sample loading solution in an appropriate well of a 96-well electrophoresis plate and covered with mineral oil. The plate was then placed in a GeXP Genetic Analysis System, which separates the PCR products by capillary electrophoresis.

Data were checked using the fragment analysis module of the GenomeLab GeXP system software and any samples lacking a peak from the internal standard, $\mathrm{Kan}^{\mathrm{r}}$, were repeated. The fragment data and peak area were then imported into the eXpress Analysis module of eXpress Profiler software, in which fragments are linked with gene information giving expression, in arbitrary fluorescence units, for each transcript within each well. This was then exported into Microsoft Excel and transcript expression was normalised within each sample by dividing the target expression by the average expression of the three control genes, giving target expression relative to GAPDH, H2AFZ and RPLPO in relative fluorescence units. Although the GeXP multiplex technology is tried and tested, by way of validation in our hands, we compared the expression of a number of genes using quantitative real-time PCR and GeXP (Supplementary Fig. 1, see section on supplementary data given at the end of this article).

\section{Western blotting}

In support of the transcript data that emerged from this study, and given that the follicular fluids collected were committed fully to steroid analyses, additional pairs of bovine ovaries were collected from a local abattoir, retaining individual animal

Table 2 Primers designed to amplify regions of the luteinising hormone/chorionic gonadotrophin receptor (LHCGR) (NM_174381) by GeXP.

\begin{tabular}{lll}
\hline Product name & Product location & Primers \\
LHCGRex2 & Exons 2-4 & $\begin{array}{l}\text { F: aggtgacactatagaatacacctatctccctatcaaagtaatcc } \\
\text { R: gtacgactcactatagggacgagggagatttgtaaacgC }\end{array}$ \\
LHCGRex8 & Exons 8-11 & F: aggtgacactatagaatagagctgaaggaaaatgcacg \\
& R: gtacgactcactatagggaggagtgtcttgggtaagcaga \\
LHCGRex11 & Within exon 11 & F: aggtgacactatagaatatgttaggcacatcaggcaaa \\
& & R: gtacgactcactatagggaccatgttcatggattggaag \\
\hline
\end{tabular}


Table 3 Structures present on the ovaries of heifers at slaughter. Group A were slaughtered at day 6 after synchronised ovulation; Group B were given prostaglandin and $\mathrm{GnRH}$ on day 6 to induce $\mathrm{CL}$ regression and ovulation on day 7 and were slaughtered on day 13; Group C were slaughtered on day 19. A: Size of the dominant follicle, and size and mass of the corpus luteum (CL), together with progesterone production. B: Oestradiol and progesterone concentrations in follicular fluids from dominant, largest subordinate and a selection of small (2-6 mm) subordinate follicles.

\begin{tabular}{|c|c|c|c|c|}
\hline & \multicolumn{3}{|c|}{ Treatment group } & \multirow[b]{2}{*}{ Probability } \\
\hline & $\mathrm{A}(n=8)$ & $\mathrm{B}(n=7)$ & $\mathrm{C}(n=8)$ & \\
\hline \multicolumn{5}{|l|}{ A } \\
\hline \multicolumn{5}{|l|}{ Size of dominant follicle } \\
\hline Diameter $(\mathrm{mm})$ & $15.12 \pm 0.85$ & $16.57 \pm 0.61$ & $14.75 \pm 0.65$ & - \\
\hline \multicolumn{5}{|l|}{ Size and mass of corpus luteum (CL) } \\
\hline Diameter $(\mathrm{mm})$ & $23.88 \pm 1.89^{\mathrm{a}}$ & $18.14 \pm 1.03^{b}$ & $21.00 \pm 0.53^{\mathrm{ab}}$ & 0.021 \\
\hline Mass (g) & $6.36 \pm 1.47^{\mathrm{a}}$ & $2.94 \pm 0.44^{\mathrm{b}}$ & $3.92 \pm 0.29^{\mathrm{ab}}$ & 0.049 \\
\hline Total P4 content (mg) & $209 \pm 81^{\mathrm{a}}$ & $31 \pm 8^{\mathrm{b}}$ & $49 \pm 8^{b}$ & 0.035 \\
\hline P4 production (ng/25 mg tissue) & $771 \pm 161^{\mathrm{a}}$ & $191 \pm 54^{b}$ & $102 \pm 35^{b}$ & $<0.001$ \\
\hline P4 synthetic capacity $(\mathrm{mg} / \mathrm{CL})$ & $163 \pm 36^{\mathrm{a}}$ & $23 \pm 8^{b}$ & $17 \pm 6^{b}$ & $<0.001$ \\
\hline B: Oestradiol (E2) and progesterone & in follicular flui & & & \\
\hline E2 $(\mathrm{ng} / \mathrm{mL})$ & & & & \\
\hline Dominant follicle & $181.4 \pm 103.5$ & $576.9 \pm 109.6$ & $407.2 \pm 109.5$ & 0.056 \\
\hline Small subordinate follicle & $0.60 \pm 0.75$ & $2.56 \pm 0.75$ & $1.43 \pm 0.76$ & - \\
\hline Largest subordinate follicle & $7.93 \pm 7.42$ & $3.51 \pm 9.82$ & $15.12 \pm 7.42$ & - \\
\hline \multicolumn{5}{|l|}{ P4 (ng/mL) } \\
\hline Dominant follicle & $81.5 \pm 11.3$ & $67.3 \pm 13.0$ & $75.7 \pm 11.3$ & - \\
\hline Small subordinate follicle & $284.3 \pm 56.3$ & $197.5 \pm 56.5$ & $85.7 \pm 56.3$ & 0.058 \\
\hline Largest subordinate follicle & $274.9 \pm 116.2$ & $234.5 \pm 124.2$ & $275.6 \pm 116.2$ & - \\
\hline \multicolumn{5}{|l|}{ E2:P4 ratio } \\
\hline Dominant follicle & $2.55 \pm 1.60$ & $8.98 \pm 1.65$ & $6.01 \pm 1.65$ & 0.054 \\
\hline Small subordinate follicle & $0.004 \pm 0.003$ & $0.022 \pm 0.008$ & $0.020 \pm 0.007$ & - \\
\hline Largest subordinate follicle & $0.25 \pm 0.20$ & $0.009 \pm 0.17$ & $0.40 \pm 0.21$ & - \\
\hline
\end{tabular}

Values are given as mean \pm SE, letters in superscript indicate significant differences $(P<0.05)$.

identity, and classified according to the stage of the oestrous cycle by assessing gross morphology of the $\mathrm{CL}$, based on the observations and classification of Ireland et al. (1980). Pairs of ovaries presenting healthy, non-atretic follicles were classified as originating from either the early follicular or early luteal phases. The largest follicle (10-14 mm) per pair of ovaries was dissected, aspirated and granulosa cells scraped and washed as described previously.

Follicular fluid samples $(5 \mu \mathrm{L})$ in Laemmli buffer were subjected to electrophoresis on 10\% SDS-polyacrylamide gels. Proteins were blotted onto nitrocellulose membrane (Optitran BA-S 83, Schleicher \& Schuell Bioscience GmbH, Dassel, Germany). Membranes were incubated for $60 \mathrm{~min}$ at $21^{\circ} \mathrm{C}$ with blocking solution (PBS, pH 7.4 with $0.05 \%$ Tween 20 and $3 \%$ non-fat milk powder) and then incubated overnight at $4{ }^{\circ} \mathrm{C}$ in the same solution containing the specific primary antiserum (rabbit anti-IGFBP-2, Upstate Biotechnology) diluted 1:1500. The membranes were washed three times with PBS-Tween and then incubated with HRP-labelled antirabbit IgG (BioRad) diluted 1:25,000 in blocking solution for $60 \mathrm{~min}$ at $21^{\circ} \mathrm{C}$. Membranes were washed twice for 10 min with PBS-Tween and once with PBS. The bands were visualised using enhanced chemiluminescence $(E C L, G E$ Healthcare) and detected on BioMax Light film (Carestream). Bands were quantified using Image J software.

\section{Statistical analysis}

All statistical analysis was performed using Genstat version 11.1.0.1504 (VSN International Ltd., Hemel-Hempstead, UK).
Necessary transformations of P4 and E2 data were determined by Box-Cox analysis. Analysis of variance (ANOVA) was used to compare E2 concentrations, P4 concentrations and gene expression between stages of the oestrous cycle. DF size, $\mathrm{CL}$ weight and $\mathrm{CL}$ size were also compared by ANOVA. For transcript analyses, a common approach in simultaneous testing is the Benjamini and Hochberg linear step-up false discovery rate (FDR) controlling procedure (Reiner et al. 2003). For such data, an FDR of $0.25(\mathrm{q})$ is typically applied to avoid a high proportion of false negatives. $P$ values $\left(P_{(1)} \leq \ldots \leq P_{(m)}\right)$ were ordered along with their respective null hypotheses $\left(H_{(1)}, \ldots, H_{(m)}\right)$, and ranked $P_{i}$ were compared with the critical value q.i $/ \mathrm{m}$. In this analysis, $k=\max i$ for which $P_{i} \leq \mathrm{q} . \mathrm{i} / \mathrm{m}$. We then rejected $H_{(1)}, \ldots, H_{(k)}$. Treatment comparisons were then made using the least significant difference test.

\section{Results}

\section{Ovarian follicle and CL development}

Shortly after the onset of oestrous synchrony (i.e. day -13; Fig. 1A), ultrasound scanning confirmed that a $C L$ was present in all eight heifers allocated to group A, 6/8 heifers allocated to group B and 6/8 heifers allocated to group $\mathrm{C}$. Ultrasound scanning on day -13 (1 day before GNRH) further confirmed the presence of follicles $\geq 8 \mathrm{~mm}$ in diameter in all the 24 heifers (size range $8-18 \mathrm{~mm}$ ). Of the two heifers in group $B$, one that did not have a CL present at the onset of synchrony subsequently failed to ovulate at day 0 (Fig. 1A), so this 
Table 4 Transcript expression in first wave (A), first wave in the presence of a sub-functional corpus luteum (B) and final wave (C) bovine dominant follicles. In general, only transcripts that differed significantly between treatment groups are shown.

\begin{tabular}{|c|c|c|c|c|}
\hline \multirow[b]{2}{*}{ Transcript } & \multicolumn{3}{|c|}{ Treatment group } & \multirow[b]{2}{*}{ Probability } \\
\hline & $\mathrm{A}(n=8)$ & $\mathrm{B}(n=7)$ & $\mathrm{C}(n=8)$ & \\
\hline \multicolumn{5}{|l|}{ Granulosa cells } \\
\hline \multicolumn{5}{|c|}{ TGF- $\beta$ superfamily } \\
\hline INHA & $0.281 \pm 0.026^{\mathrm{a}}$ & $0.272 \pm 0.046^{\mathrm{a}}$ & $0.132 \pm 0.043^{b}$ & 0.020 \\
\hline INHBA & $0.948 \pm 0.060^{\mathrm{a}}$ & $0.769 \pm 0.093^{\mathrm{ab}}$ & $0.500 \pm 0.132^{b}$ & 0.015 \\
\hline \multicolumn{5}{|c|}{ Insulin/IGF family } \\
\hline$I G F 2 R$ & $0.100 \pm 0.012$ & $0.092 \pm 0.009$ & $0.159 \pm 0.037$ & 0.122 \\
\hline IGFBP2 & $0.200 \pm 0.029$ & $0.166 \pm 0.014$ & $0.353 \pm 0.086$ & 0.059 \\
\hline \multicolumn{5}{|c|}{ Steroidogenic mediators } \\
\hline CYP11A1 & $0.545 \pm 0.048^{\mathrm{a}}$ & $0.462 \pm 0.050^{\mathrm{a}}$ & $0.273 \pm 0.079^{b}$ & 0.015 \\
\hline CYP19A1 & $2.955 \pm 0.145^{\mathrm{a}}$ & $2.411 \pm 0.121^{\mathrm{a}}$ & $1.195 \pm 0.315^{b}$ & $<0.001$ \\
\hline ESR2 & $0.231 \pm 0.029^{\mathrm{a}}$ & $0.199 \pm 0.025^{\mathrm{ab}}$ & $0.123 \pm 0.024^{b}$ & 0.024 \\
\hline HSD3B1 & $0.229 \pm 0.028^{\mathrm{a}}$ & $0.205 \pm 0.025^{\mathrm{ab}}$ & $0.112 \pm 0.038^{b}$ & 0.036 \\
\hline SCARB1 & $0.433 \pm 0.062$ & $0.492 \pm 0.062$ & $0.2839 \pm 0.066$ & 0.083 \\
\hline \multicolumn{5}{|c|}{ Angiogenic regulators } \\
\hline HIF1A & $0.984 \pm 0.053^{\mathrm{a}}$ & $0.951 \pm 0.064^{\mathrm{a}}$ & $0.668 \pm 0.091^{b}$ & 0.009 \\
\hline \multicolumn{5}{|c|}{ Miscellaneous } \\
\hline PTGFR & $0.034 \pm 0.004^{\mathrm{a}}$ & $0.025 \pm 0.007^{\mathrm{ab}}$ & $0.013 \pm 0.005^{b}$ & 0.038 \\
\hline SRSF9 & $0.601 \pm 0.037$ & $0.569 \pm 0.031$ & $0.493 \pm 0.032$ & 0.079 \\
\hline \multicolumn{5}{|l|}{ Thecal cells } \\
\hline \multicolumn{5}{|c|}{ Insulin/IGF family } \\
\hline$I G F 2 R$ & $0.080 \pm 0.009^{a}$ & $0.102 \pm 0.014^{\mathrm{ab}}$ & $0.136 \pm 0.012^{b}$ & 0.011 \\
\hline IGFBP2 & $0.211 \pm 0.028^{\mathrm{a}}$ & $0.216 \pm 0.045^{a}$ & $0.366 \pm 0.053^{b}$ & 0.030 \\
\hline \multicolumn{5}{|c|}{ Steroidogenic mediators } \\
\hline SCARB 1 & $0.272 \pm 0.048^{\mathrm{a}}$ & $0.535 \pm 0.073^{b}$ & $0.505 \pm 0.099^{b}$ & 0.047 \\
\hline \multicolumn{5}{|l|}{ Cytokines } \\
\hline PTPRC & $0.044 \pm 0.006^{\mathrm{a}}$ & $0.048 \pm 0.007^{a}$ & $0.094 \pm 0.017^{b}$ & 0.011 \\
\hline
\end{tabular}

Values are mean \pm SE in arbitrary fluorescence units relative to the control genes GAPDH, H2AFZ and RPLPO. Letters in superscript indicate significant differences $(P<0.05)$. Reported transcripts (other than IGF2R in granulosa cells) lie within the FDR threshold of 0.25 .

animal was removed from any further analysis. All other animals ovulated between 11 am on day -1 and $11 \mathrm{am}$ on day +1 as expected, and diameter of the ovulatory follicle (i.e. its last recorded diameter as determined by ultrasound scanning) did not differ between groups (mean \pm S.E.M. of $13.4 \pm 2.62 \mathrm{~mm}$ ). Similarly, DF and $\mathrm{CL}$ diameter on day 5 did not differ between groups (mean values of $11.6 \pm 2.02 \mathrm{~mm}$ and $18.7 \pm 4.32 \mathrm{~mm}$ respectively). Plasma P4 concentrations were also found not to differ between groups before day 6 (Fig. 1B). Of the seven animals remaining in group $B$, all underwent luteal regression, resulting in a decrease in plasma $\mathrm{P} 4$ concentrations (Fig. 1B) and ovulated between $11 \mathrm{am}$ on day 6 and 11 am on day 8 . Response to GNRH was supported by an immediate increase $(P<0.001)$ in plasma LH (from $1.0 \pm 0.64 \mathrm{pg} / \mathrm{mL}$ at the time of GNRH administration to $8.7 \pm 0.83 \mathrm{ng} / \mathrm{mL} 2 \mathrm{~h}$ later), followed by disappearance of the DF within $48 \mathrm{~h}$. Ovulatory follicle diameter was compared between the initial, synchronised ovulation (groups A, B and C; day 0) and induced ovulation (group B; day 7); however, no significant difference was detected $(13.4$ vs $12.0 \mathrm{~mm}$ $(P=0.09)$ measured on days- 1 and 6 respectively; Supplementary Fig. 3A). Furthermore, when it came to killing, there was no difference in DF diameter between groups (Table 3A). However, CLs collected from group $\mathrm{B}$ at killing were smaller $(P=0.021)$ and weighed less $(P=0.049)$ than those collected from group A (Table 3A). Of the eight heifers in group $C$, three had a two-wave cycle, four had a three-wave cycle and one had a fourwave cycle. For DFs at killing in these animals, the time interval from initial visualisation $(\leq 2 \mathrm{~mm})$ to killing was $8.25 \pm 0.48$ vs $6.0 \pm 0.57$ days $(P=0.024)$ for two- and three-wave cycles respectively. There was no significant difference in diameter of the DF between two- vs threewave cycles $(15.5 \pm 1.29$ vs $14.0 \pm 2.16 \mathrm{~mm})$. Similarly, there was no difference in FF steroid concentrations between these two groups (E2: $402 \pm 172$ vs $412 \pm 156 \mathrm{ng} /$ $\mathrm{mL}$; 4 : $69 \pm 13$ vs $83 \pm 46 \mathrm{ng} / \mathrm{mL})$.

\section{CL progesterone-producing capacity}

Total P4 content (amount of P4 per CL), P4 production (amount of $\mathrm{P} 4$ produced per unit of tissue cultured $\left.=\mathrm{P} 4_{\text {tissue }}+\mathrm{P} 4_{\text {media }}-\mathrm{P} 4_{\text {initial tissue }}\right)$ and $\mathrm{P} 4$ synthetic capacity (P4 production corrected for total CL weight) were greater $(P=0.035,<0.001$ and $<0.001$ respectively) for group A than for either group B or C (Table 3A). Furthermore, analyses indicated that diameter of the follicle destined to ovulate was positively $(P=0.001)$ correlated with diameter of the resulting $\mathrm{CL} 6$ days after ovulation for DFs scanned on day -1 , but not for DFs scanned on day 6 (i.e. group B) (Supplementary Fig. 3A). However, diameter of the resulting CL was not correlated with its $\mathrm{P} 4$ synthetic capacity for either group A or B treatments (Supplementary Fig. 3B), indicating that size of these structures alone does not explain $\mathrm{CL}$ functionality. 
Table 5 Transcript expression in 6-day-old spontaneous (A), 6-day-old induced (B) and 19-day-old regressing (C) bovine corpora lutea. Only transcripts that differed between treatment groups are shown. Abundance of three regions (LHCGRex11, LHCGRex2 and LHCGRex8) with two splice variants lacking exon 3 (LHCGRex2(-3)) and exon 9 (LHCGRex8(-9)) of the LHCGR transcript is given.

\begin{tabular}{|c|c|c|c|c|}
\hline \multirow[b]{2}{*}{ Transcript } & \multicolumn{3}{|c|}{ Treatment group } & \multirow[b]{2}{*}{ Probability } \\
\hline & $\mathrm{A}(n=8)$ & $\mathrm{B}(n=7)$ & $\mathrm{C}(n=8)$ & \\
\hline \multicolumn{5}{|l|}{ TGF- $\beta$ superfamily } \\
\hline$B M P 2$ & $0.003 \pm 0.002^{\mathrm{a}}$ & $0.021 \pm 0.006^{b}$ & $0.020 \pm 0.006^{b}$ & 0.037 \\
\hline INHBA & $0.017 \pm 0.006^{\mathrm{a}}$ & $0.039 \pm 0.013^{a, b}$ & $0.063 \pm 0.009^{b}$ & 0.009 \\
\hline$I N H B B$ & $0.016 \pm 0.004^{\mathrm{a}}$ & $0.038 \pm 0.016^{\mathrm{a}, \mathrm{b}}$ & $0.063 \pm 0.012^{b}$ & 0.027 \\
\hline \multicolumn{5}{|l|}{ Insulin/IGF family } \\
\hline IGFBP4 & $0.228 \pm 0.037^{a}$ & $0.116 \pm 0.016^{b}$ & $0.134 \pm 0.031^{b}$ & 0.038 \\
\hline IGFBP5 & $0.266 \pm 0.022^{\mathrm{a}}$ & $0.550 \pm 0.086^{b}$ & $0.635 \pm 0.121^{b}$ & 0.016 \\
\hline \multicolumn{5}{|c|}{ Steroidogenic mediators } \\
\hline CYP11A1 & $0.933 \pm 0.065^{\mathrm{a}}$ & $0.720 \pm 0.126^{\mathrm{a}}$ & $0.466 \pm 0.036^{b}$ & 0.002 \\
\hline HSD $3 B 1$ & $0.637 \pm 0.032^{\mathrm{a}}$ & $0.415 \pm 0.126^{b}$ & $0.078 \pm 0.024^{c}$ & $<0.001$ \\
\hline SCARB1 & $1.722 \pm 0.092^{\mathrm{a}}$ & $1.493 \pm 0.210^{\mathrm{a}}$ & $1.038 \pm 0.085^{b}$ & 0.005 \\
\hline STAR & $1.350 \pm 0.061^{\mathrm{a}}$ & $0.837 \pm 0.185^{b}$ & $0.266 \pm 0.053^{c}$ & $<0.001$ \\
\hline \multicolumn{5}{|l|}{ Cytokines } \\
\hline ILIB & $0.307 \pm 0.027^{\mathrm{a}}$ & $0.246 \pm 0.026^{a, b}$ & $0.182 \pm 0.025^{b}$ & 0.011 \\
\hline IL8 & $0.039 \pm 0.010^{\mathrm{a}}$ & $0.062 \pm 0.013^{\mathrm{a}}$ & $0.166 \pm 0.038^{b}$ & 0.004 \\
\hline KITLG & $0.046 \pm 0.008^{a}$ & $0.024 \pm 0.004^{b}$ & $0.002 \pm 0.004^{c}$ & $<0.001$ \\
\hline MIF & $0.037 \pm 0.003^{\mathrm{a}}$ & $0.034 \pm 0.006^{\mathrm{a}}$ & $0.012 \pm 0.004^{b}$ & $<0.001$ \\
\hline \multicolumn{5}{|c|}{ Apoptotic regulators } \\
\hline GADD $45 B$ & $0.444 \pm 0.028^{a}$ & $0.295 \pm 0.040^{b}$ & $0.231 \pm 0.034^{b}$ & $<0.001$ \\
\hline \multicolumn{5}{|c|}{ Angiogenic regulators } \\
\hline HIF1A & $0.674 \pm 0.034^{\mathrm{a}}$ & $0.612 \pm 0.039^{a, b}$ & $0.441 \pm 0.047^{b}$ & 0.002 \\
\hline VEGFA & $0.037 \pm 0.009^{a}$ & $0.009 \pm 0.005^{b}$ & ND & 0.002 \\
\hline \multicolumn{5}{|l|}{ Miscellaneous } \\
\hline PTGFR & $0.500 \pm 0.045^{\mathrm{a}}$ & $0.304 \pm 0.056^{b}$ & $0.144 \pm 0.036^{c}$ & $<0.001$ \\
\hline SRSF9 & $0.579 \pm 0.046$ & $0.621 \pm 0.027$ & $0.479 \pm 0.042$ & 0.075 \\
\hline \multicolumn{5}{|c|}{ Luteinizing hormone receptor variants } \\
\hline LHCGRex2 & $0.392 \pm 0.054^{\mathrm{a}}$ & $0.218 \pm 0.085^{b}$ & $0.003 \pm 0.002^{c}$ & $<0.001$ \\
\hline LHCGRex2(-3) & $0.059 \pm 0.012^{\mathrm{a}}$ & $0.017 \pm 0.010^{b}$ & ND & $<0.001$ \\
\hline LHCGRex8 & $0.012 \pm 0.007$ & ND & ND & - \\
\hline LHCGRex8 $(-9)$ & $0.019 \pm 0.009$ & ND & ND & - \\
\hline LHCGRex 11 & $0.428 \pm 0.048^{a}$ & $0.281 \pm 0.137^{\mathrm{a}}$ & $0.001 \pm 0.001^{b}$ & 0.003 \\
\hline
\end{tabular}

Values are mean \pm S.E.M. in arbitrary fluorescence units relative to the control genes GAPDH, H2AFZ and RPLPO. Letters in superscript indicate significant differences $(P<0.05)$, ND means none detected. Reported transcripts lie within the FDR threshold of 0.25 .

\section{Follicular fluid hormone concentrations}

As one might expect, follicular fluid P4 concentration was greater $(P<0.05)$ in small follicles than in DFs, and E2 concentration was greater $(P<0.001)$ in DFs than in small follicles (Table 3B). There was a strong indication $(P=0.058)$ that $\mathrm{P} 4$ concentrations were greater in small follicles from group $A$ than in small follicles from groups $\mathrm{B}$ and $\mathrm{C}$. There was also a strong indication $(P=0.056)$ that E2 concentrations were lower in follicular fluids from DFs in group A than in follicular fluids from either groups $\mathrm{B}$ or $\mathrm{C}$. This observation was supported by a lower $(P=0.054) \mathrm{E} 2: \mathrm{P} 4$ ratio in DF fluids from group $\mathrm{A}$ compared with groups $\mathrm{B}$ and $\mathrm{C}$.

\section{Transcript expression}

Transcripts for AMH, BMP2, BMP6, ESR1, FGF1, IGF2, CYP17A1, IL2, IL6, MIF and PGR were not detected in granulosa cells. Similarly, transcripts for $A M H, B M P 2$, BMP6, FGF1, CYP19A1, IL2, IL6, MIF and VEGFA mRNA were not detected in thecal cells, and transcripts for AMH, BMP6, FGF1, IL2, IL6, INHA, LRP8 and PGR mRNA were not detected within the CL. Although expressed in our mixed population of ovarian cells during GeXP platform development, the following genes were not expressed in any of our experimental cell types: AMH, BMP6, FGF1, IL2 and IL6 (Supplementary Materials and results).

In granulosa cells, expression of INHA, INHBA, CYP11A1, CYP19A1, ESR2, HSD3B1, HIF1A and PTGFR was greater $(P<0.05)$ in group A (first-wave DF) than in group $C$ (final-wave DF) (Table 4). In thecal cells, expression of IGF2R, IGFBP2, SCARB1 and PTPRC was lower $(P<0.05)$ in group $A$ than in group $C$ (Table 4$)$. Interestingly, thecal cell SCARB 1 expression was lower $(P<0.05)$ in group $\mathrm{A}$ than in group $\mathrm{B}$, and expression of PTGFR was only detectable in thecal cells from group B (data not shown). LHCGR splice variant expression within granulosa and also thecal cells of the DF did not differ with the stage of the oestrous cycle.

Many more of our selected transcripts were differentially expressed in the $\mathrm{CL}$ (Table 5) than in either granulosa or thecal cells (Table 4). For the $\mathrm{CL}$, 


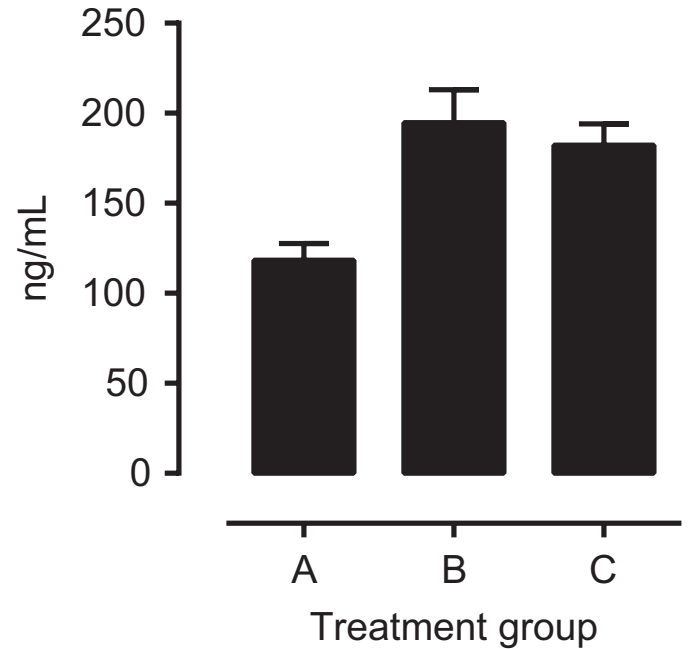

Figure 2 Plasma IGF1 concentrations at the point of killing for 24 Hereford $\times$ Holstein heifers. Animals were synchronised (Fig. 1) and then group A animals were killed at day 6 (after initial synchronised ovulation); group B animals were induced to ovulate on day 7 and killed on day 13; group $C$ animals were killed on day 19. Plasma IGF1 concentrations were lower $(P=0.001)$ in group $A$ than in group $\mathrm{B}$ and $\mathrm{C}$ animals.

the greatest differences in transcript expression were between groups A and C; transcript expression for group B often was intermediate to these contrasting levels.

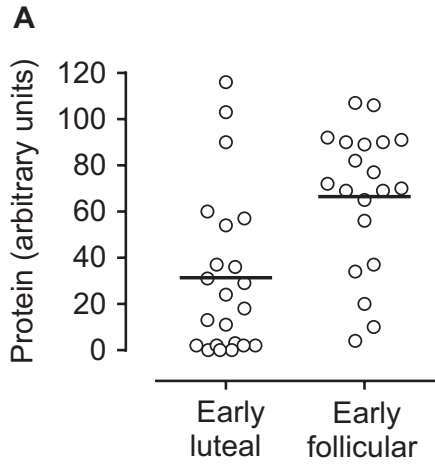

B

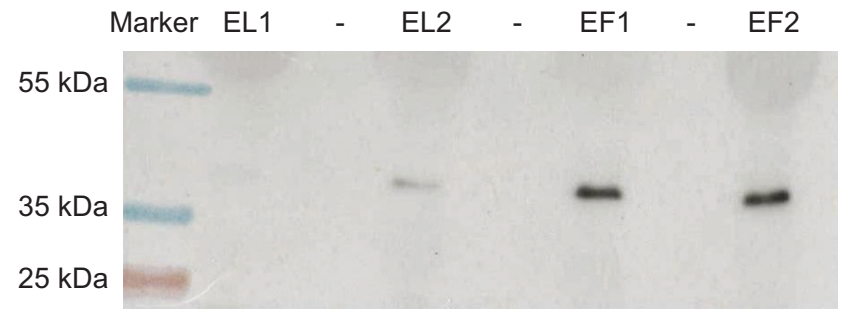

Figure 3 Follicular fluid IGFBP2 protein concentration (from cycle stage-determined abattoir-derived ovaries) was greater $(P<0.001)$ in early follicular than early luteal phase dominant follicles (A). IGFBP2 was quantified by western blotting. (B) A typical gel for follicular fluid from two early luteal (EL1 and EL2) and two early follicular (EF1 and EF2) phase dominant follicles, with alternative lanes left blank (-).
Given that the comparison of particular interest lies between groups $\mathrm{A}$ and $\mathrm{B}$, it is noteworthy that $B M P 2$ and IGFBP5 expression was lower in CLs from group $\mathrm{A}$ than from group $B$. In contrast, expression of IGFBP4, HSD3B1, STAR, KITLG, GADD45B, VEGFA, PTGFR, LHCGRex2, -ex2(-3), -ex8 and -ex8(-9) was greater for group A than for group B.

\section{Plasma IGF1 concentration}

At day 0 (Fig. 1), plasma IGF1 concentration was $148 \pm 47 \mathrm{ng} / \mathrm{mL}$ and did not differ between treatment groups. At the point of killing, however, plasma IGF1 was significantly lower $(P=0.001)$ in heifers from group A than from groups B and C (Fig. 2).

\section{IGF2R and IGFBP2 expression in supplementary abattoir ovaries}

In granulosa cells harvested from cycle stagedetermined abattoir-derived ovaries, relative expression of IGF2R and IGFBP2 was greater $(P=0.004)$ in cells from early follicular phase (similar to group $C$ ) than early luteal phase (similar to group A) dominant follicles $(0.267 \pm 0.022$ vs $0.188 \pm 0.018$ for IGF2R; $0.631 \pm 0.060$ vs $0.353 \pm 0.050$ for IGFBP2). In agreement with transcript abundance, the concentration of IGFBP2 protein in follicular fluid was greater $(P<0.001)$ from early follicular than early luteal phase DFs (Fig. 3).

\section{Discussion}

This study reports a number of key findings. Both the mass and P4-synthesising capacity of a CL formed following induced ovulation of a first-wave DF (i.e. CLs from group $B$ in this study) were reduced relative to a $\mathrm{CL}$ formed following spontaneous ovulation (i.e. CLs from group A). Indeed, the P4 synthetic capacity of these induced (i.e. group B) CLs was similar to that of a regressing $\mathrm{CL}$ (i.e. group $\mathrm{C}$ ) during the pro-oestrous phase of the cycle and, at a molecular level, they were characterised as having reduced expression of steroidogenic enzymes (i.e. STAR and HSD3B1) involved in cholesterol transfer into mitochondria and conversion of pregnenolone to progesterone. These induced CLs were further characterised as having reduced expression of $L H C G R$ (required for luteal support; Niswender et al. 2007) and VEGFA (a key angiogenic regulator; Robinson et al. 2007), together with increased expression of BMP2 (linked to luteolysis in regressing CLs; Nio-Kobayashi et al. 2015).

Regarding follicular development, relative to finalwave DFs (i.e. those from group C at day 19), key functional features of first-wave DFs (i.e. those from group A at day 6 , coinciding with GNRH treatment in group B) 
included reduced E2 concentrations and a reduced E2:P4 ratio. These differences occurred in the face of increased transcript expression of key steroidogenic enzymes (i.e. CYP11A1 (encoding cholesterol sidechain cleavage), HSD3B1 and CYP19A1 (encoding aromatase)) in granulosa cells and reduced expression of SCARB1 (which facilitates cellular cholesterol uptake from high-density lipoproteins; Azhar et al. 1998) in thecal cells. Also difference between these two DF groups were transcripts for two inhibin/activin subunits (i.e. INHA and INHBA), which were both increased in first-wave DFs relative to final-wave DFs. Importantly, given that background plasma and follicular fluid $\mathrm{P} 4$ levels were similar between groups A and B (Fig. 1B and Table 3B), it is noteworthy that transcript expression for a range of genes in granulosa and thecal cells from both groups $A$ and $B$ were also similar, highlighting the importance of $\mathrm{P} 4$ as a regulator of follicular maturation. Finally, it is also worth noting the differences in transcript expression of IGF2R and IGFBP2 in both granulosa and thecal cells, and protein expression of IGFBP2 in follicular fluid, between first- and final-wave DFs (i.e. group A vs group C). These were consistently lower in first-wave relative to final-wave DFs, when circulating levels of IGF1 were also at their lowest (Fig. 3). These differences seem to be of key significance given that these IGF family members each serve to regulate the bioavailability of both IGF-1 and -2 within the ovarian follicle (Webb and Campbell 2007). However, the issue of proximity to PG administration cannot be discounted. Indeed, PTCFR expression was lower in group $C$ ovarian cells (i.e. granulosa and luteal) than in group $A$, with group $B$ in between. This could be due to direct or indirect actions of PG.

Collectively, these results indicate an important role of P4 during terminal follicle maturation that determines subsequent luteal competence, although the effects of endogenous $\mathrm{LH}$, which are well established (e.g. Quintal-Franco et al. 1999) but not determined in this study, and differences in the nature and timing of pharmacological intervention (i.e. PG relative to endogenous or administered GNRH) between groups cannot be discounted. Indeed, in sheep, Murdoch and Van Kirk (1998) found that premature induction of ovulation (i.e. $12 \mathrm{~h}$ vs $36 \mathrm{~h}$ after PG-induced luteolysis) compromised the formation of a functionally competent $\mathrm{CL}$. In this study, follicles that gave rise to less competent CLs were less oestrogenic than those that gave rise to more competent CLs and the data point to underlying contributions by components of both the TGF and IGF systems.

\section{The 'final-wave' dominant follicle}

In this study, one could consider the DF that ovulated around day 0 to be representative of a 'final-wave' DF, although it is recognised that this follicle did not occur in a natural, uncontrolled oestrous cycle, but rather in one in which both follicle and CL developments were regulated and synchronised (Fig. 1). This was necessary for experimental purposes as it standardised follicle development to a more precisely timed ovulation. From the perspective of assisted reproduction, it is also representative of protocols routinely used for oestrous synchronisation. Furthermore, ovulation of the resultant DF was induced by the endogenous surge of LH that followed the second prostaglandin treatment, and thus more closely resembles the natural ovulatory process than that represented by the GNRH-induced ovulation of a day 6 DF. However, this 'final-wave' DF (i.e. destined to ovulate around day 0 ) probably developed under a low P4 environment (not determined), given that PG administration preceded GNRH treatment during the initial synchrony programme (Fig. 1A). In contrast, the DFs harvested from group C heifers on day $19(24 \mathrm{~h}$ after PG) better represent the normal final-wave, preovulatory follicle.

\section{Corpus luteum}

In bovine-assisted reproduction, either follicle ablation or aspiration (to recover ova) close to the anticipated time of ovulation leads to the formation of small CLs, with reduced capacity to produce and secrete $\mathrm{P} 4$ (O'Hara et al. 2012). This reduction in P4 secretion is, in turn, associated with reduced expression of LHCGR in luteal tissue. These authors commented that this may be due in part to removal of a variable number of granulosa cells that would otherwise have contributed to luteal formation; although given the preferential localisation of LHCGR to small (i.e. theca derived) luteal cells (Yuan \& Lucy 1996, Mamluk et al. 1998), it is uncertain whether this alone could account for reduced LHCGR expression. The study of Hayashi et al. (2006), however, highlighted the importance of appropriate LH priming before GNRH-induced ovulation for the formation of functionally competent CLs. In this study, DFs from group C best represent 'final-wave' (pre-ovulatory) DFs; however, the timing of their collection (i.e. 24-h post PG administration; Fig. 1) probably precluded exposure to surge levels of LH. In contrast, the 'final-wave' DF that gave rise to a day $6 \mathrm{CL}$ (group A) will probably have been 'older' and larger at the point of ovulation, and almost certainly would have been exposed to higher levels of $\mathrm{LH}$; although these parameters were not determined. Therefore, while molecular features of group $\mathrm{C}$ relative to group A DFs (discussed later) provide important information on factors regulating subsequent $C L$ function, they probably do not represent the complete picture.

\section{Molecular basis of luteal support and steroidogenesis}

The reduced capacity of induced (group B) CLs to produce P4 is consistent with the reduced expression of STAR 
and HSD3B1 observed (Table 5). Reduced expression of transcripts for IGFBP4 and increased expression of transcripts for IGFBP5 in group C (regressing), relative to group A (developing), CLs is consistent with earlier reports of $\mathrm{CL}$ demise following $\mathrm{PGF}_{2 \alpha}$-induced luteolysis in cattle (Neuvians et al. 2003) and sheep (Hastie \& Haresign 2006). Although IGFBP4 generally inhibits IGF action, IGFBP5 is known to have both IGF-dependent and -independent effects but is generally associated with growth arrest and apoptosis (Kelley et al. 1996, Monget et al. 1998). What is interesting in this study is that transcript expression for these two binding proteins in group B CLs more closely matches that of group C than group A CLs which, when considered with the P4 data in Table 3, lends further support to the functional inadequacy of these induced CLs. Closer inspection of Table 5 data, however, indicates that there are numerous molecular differences between group B and C CLs, not least of which is transcript expression for steroidogenic enzymes and key cytokines, indicating that while these CLs may be developmentally compromised, they nevertheless retained some residual function.

VEGFA is a potent mitogen that promotes the growth, migration and permeability of vascular endothelial cells in CLs throughout the luteal phase (Robinson et al. 2007). Levels of this protein within the $\mathrm{CL}$ peak at around day 15 of the oestrous cycle but decline on luteolysis as witnessed in this study (Table 5) and by Guzmán et al. (2015). This latter study also demonstrated that there are both pro- and anti-angiogenic isoforms of VEGFA in the bovine $\mathrm{CL}$, and that immediately before luteolysis, there is an increase in anti-angiogenic isoforms. With respect to the various isoforms identified by Guzmán et al. (2015), we can deduce from the primers designed for this study that we amplified the single isoform 205, which has only been described as pro-angiogenic. Increased expression of this isoform in group A CLs, relative to group B and C CLs, further serves to confirm their viability.

Several alternatively spliced variants of the LHCGR gene have also been reported in the bovine ovary, but only a couple of these variants with open reading frames over the entire sequence are capable of producing a fully functional receptor (Robert et al. 2003). The variants reported include a complete deletion of exon 10 and/ or partial deletion of exon 11, and there is also a loss of exon 3 in bovine granulosa cells (Nogueira et al. 2007). In humans, a splice variant lacking exon 10 produces a protein capable of binding hCG, but not LH (Müller et al. 2003) and, in keeping with a further human splice variant lacking exon 9, can form complexes with other LHCGR isoforms to reduce overall receptor expression and cAMP accumulation (Nakamura et al. 2004, Ndiaye et al. 2005, Minegishi et al. 2007). Primer design in this study (Table 1) allowed us to confirm the expression of LHCGR transcripts lacking exons 3 and 9; however, we were unable to detect transcripts lacking exon 10 in any of the somatic (i.e. granulosa, thecal and luteal) cells studied in the ovary. Relative to CLs from group $\mathrm{A}$ (formed from 'final-wave' DFs), expression of all LHCGR variants was reduced in CLs from group $B$ (derived from first-wave DFs) and was barely detectable in regressing CLs (group C) (Table 5). Based on quantitative measurements of LHCGR expression within the bovine $\mathrm{CL}$ during a regular oestrous cycle (Yoshioka et al. 2013), we surmise that group B CLs in this study were more similar to regular day 2-3 CLs than day 5-7 CLs. This point is consistent with reduced levels of $\mathrm{P} 4$ production by group $\mathrm{B}$ relative to group A CLs (Table $3 \mathrm{~A}$ ).

\section{Molecular features of DFs that give rise to CLs}

In this study, group C DFs were more oestrogenic than group A DFs (Table 3B); however, transcript expression for ESR2, three steroidogenic enzymes (CYP11A1, HSD3B1 and CYP19A1) and subunits for inhibin-A and activin-A were decreased (Table 4). These features are consistent with a number of previous observations. For example, increasing levels of LH (Byers et al. 1997) and ovarian oestrogens (Sharma et al. 1999) are each known to down-regulate ESR2 expression in granulosa cells and, in cattle, levels of inhibin-A and activin-A in follicular fluid are reduced in large $(13-20 \mathrm{~mm})$ follicles with high $(>5)$ compared with low $(<5) \mathrm{E} 2: \mathrm{P} 4$ ratios (Glister et al. 2006). Peripheral (Armstrong et al. 2001) and follicular (Echternkamp et al. 1994) concentrations of IGF1 also increase under these oestrogen-dominated conditions (Fig. 3) as animals enter the follicular phase. Expression of uterine IGFBP2 mRNA and protein increases towards the late luteal phase and is thought to be under the regulation of P4 (McCarthy et al. 2012, Costello et al. 2014). Elevated expression of IGFBP2 transcripts in group C DFs (Table 4) and IGFBP2 protein in follicular phase fluids (Fig. 3 ) is consistent with these observations but, on first inspection, is somewhat at odds with earlier studies that indicate that IGFBP2 levels in follicular fluids decrease in large oestrogen-active and pre-ovulatory follicles (Echternkamp et al. 1994, Funston et al. 1996). However, in contrast to previous work, this study compared DFs of equivalent size but at different stages of the oestrous cycle. Furthermore, it is noteworthy that (i) follicles were harvested in both luteal and early follicular phases, and (ii) E2:P4 ratios were only slightly greater for group $\mathrm{C}$ than for group A DFs (Table 3B) and were similar for abattoir-derived early luteal and early follicular phase DFs $(1.27 \pm 0.96$ vs $2.2 \pm 1.50$ respectively). Western blot analyses also revealed proteolytic fragments of IGFBP2 in early follicular phase DFs (data not shown), suggesting initial stages of degradation at the onset of this oestrogen-dominated period. Collectively, these data suggest the presence of an active IGF regulatory system in final-wave DFs to tightly control cellular responses to increased circulating IGF1. 


\section{Conclusions}

The foregoing discussion focused on differences in functional competency and transcript expression of CLs derived following induced and spontaneous ovulations, together with differences in transcript expression of DFs that give rise to these structures. This study confirms that induced ovulation of a first-wave DF results in the formation of a smaller $\mathrm{CL}$ with functionally lower P4 production than one formed following spontaneous ovulation. Furthermore, these smaller induced CLs were characterised as having reduced expression of transcripts required for luteal support, angiogenesis and steroidogenesis, together with increased expression of transcripts associated with luteolysis. Importantly, these differences in $C L$ function were not related to size of the ovulated DF but were associated with their steroidogenic activity. Transcript expression differed between first- and final-wave DFs and was associated with peripheral and local levels of P4 and components of the IGF system. These data indicate that these separate follicular systems interact to affect maturation of the ovulatory follicle transiting from di-oestrus to pro-oestrus in a manner that subsequently alters the functional competency of the CL.

\section{Supplementary data}

This is linked to the online version of the paper at http://dx.doi. org/10.1530/REP-15-0415.

\section{Declaration of interest}

The authors declare that there is no conflict of interest that could be perceived as prejudicing the impartiality of the research reported.

\section{Funding}

This research did not receive any specific grant from any funding agency in the public, commercial or not-for-profit sector. EG was supported by a Doctoral Account from the University of Nottingham.

\section{Acknowledgements}

Technical assistance was provided by Neil Saunders, Dr Kamila Derecka, Marcus Mitchell, Morag Hunter, Ralph Hourd, Tim Allen, Linda Staniforth and the BSU staff at the University of Nottingham.

\section{References}

Agricultural and Food Research Council (AFRC) 1993 Energy and Protein Requirements of Ruminants. An Advisory Manual Prepared by the AFRC Technical Committee on Responses to Nutrients. Wallingford, UK: CAB International.

Armstrong DG, McEvoy TG, Baxter G, Robinson JJ, Hogg CO, Woad KJ, Webb R \& Sinclair KD 2001 Effect of dietary energy and protein on bovine follicular dynamics and embryo production in vitro: associations with the ovarian insulin-like growth factor system. Biology of Reproduction 64 1624-1632. (doi:10.1095/biolreprod64.6.1624)

Azhar S, Tsai L, Medicherla S, Chandrasekher Y, Giudice L \& Reaven E 1998 Human granulosa cells use high density lipoprotein cholesterol for steroidogenesis Journal of Clinical Endocrinology and Metabolism 83 983-991. (doi:10.1210/jcem.83.3.4662)

Bisinotto RS, Chebel RC \& Santos JEP 2010 Follicular wave of the ovulatory follicle and not cyclic status influences fertility of dairy cows. Journal of Dairy Science 93 3578-3587. (doi:10.3168/jds.2010-3047)

Bisinotto RS, Ribeiro ES \& Santos JEP 2014 Synchronisation of ovulation for management of reproduction in dairy cows. Animal 8 151-159. (doi:10.1017/S1751731114000858)

Byers M, Kuiper GG, Gustafsson JA \& Park-Sarge OK 1997 Estrogen receptor-beta mRNA expression in rat ovary: down-regulation by gonadotropins. Molecular Endocrinology 11 172-182. (doi:10.1210/ mend.11.2.9887)

Colazo MG, Dourey A, Rajamahendran R \& Ambrose DJ 2013 Progesterone supplementation before timed $\mathrm{Al}$ increased ovulation synchrony and pregnancy per Al, and supplementation after timed Al reduced pregnancy losses in lactating dairy cows. Theriogenology 79 833-841. (doi:10.1016/j.theriogenology.2012.12.011)

Costello LM, O'Boyle P, Diskin MG, Hynes AC \& Morris DG 2014 Insulinlike growth factor and insulin-like growth factor-binding proteins in the bovine uterus throughout the oestrous cycle. Reproduction, Fertility and Development 26 599-608. (doi:10.1071/RD13105)

Echternkamp SE, Howard HJ, Roberts AJ, Grizzle J \& Wise T 1994 Relationships among concentrations of steroids, insulin-like growth factor-I, and insulin-like growth factor binding proteins in ovarian follicular fluid of beef cattle. Biology of Reproduction 51 971-981. (doi:10.1095/biolreprod51.5.971)

Funston RN, Seidel GE Jr, Klindt J \& Roberts AJ 1996 Insulin-like growth factor I and insulin-like growth factor-binding proteins in bovine serum and follicular fluid before and after the preovulatory surge of luteinizing hormone. Biology of Reproduction 55 1390-1396. (doi:10.1095/ biolreprod55.6.1390)

Ginther OJ, Kastelic JP \& Knopf L 1989 Composition and characteristics of follicular waves during the bovine oestrous cycle. Animal Reproduction Science 20 187-200. (doi:10.1016/0378-4320(89)90084-5)

Glister C, Groome NP \& Knight PG 2006 Bovine follicle development is associated with divergent changes in activin- $A$, inhibin $A$ and follistatin and the relative abundance of different follistatin isoforms in follicular fluid. Journal of Endocrinology 188 215-225. (doi:10.1677/ joe.1.06485)

Guzmán A, Macías-Valencia R, Fierro-Fierro F, Gutiérrez CG \& RosalesTorres AM 2015 The corpora lutea proangiogenic state of VEGF system components is turned to antiangiogenic at the later phase of the oestrous cycle in cows. Animal 9 301-307. (doi:10.1017/ S1751731114002274)

Hastie PM \& Haresign W 2006 A role for LH in the regulation of expression of mRNAs encoding components of the insulin-like growth factor (IGF) system in the ovine corpus luteum. Animal Reproduction Science 96 196-209. (doi:10.1016/j.anireprosci.2005.12.009)

Hayashi KG, Matsui M, Acosta TJ, Kida K \& Miyamoto A 2006 Effect of the dominant follicle aspiration before or after luteinizing hormone surge on the corpus luteum formation in the cow. Journal of Reproduction and Development 52 129-135. (doi:10.1262/jrd.17049)

Ireland JJ, Murphee RL \& Coulson PB 1980 Accuracy of predicting stages of bovine estrous cycle by gross appearance of the corpus luteum. Journal of Dairy Science 63 155-160. (doi:10.3168/jds.S0022-0302(80)82901-8)

Kanakkaparambil R, Singh R, Li D, Webb R \& Sinclair KD 2009 B-vitamin and homocysteine status determines ovarian response to gonadotropin treatment in sheep. Biology of Reproduction 80 743-752. (doi:10.1095/ biolreprod.108.072074)

Kelley KM, Oh Y, Gargosky SE, Gucev Z, Matsumoto T, Hwa V, Ng L, Simpson DM \& Rosenfeld RG 1996 Insulin-like growth factor-binding proteins (IGFBPs) and their regulatory dynamics. International Journal of Biochemistry and Cell Biology 28 619-637. (doi:10.1016/13572725(96)00005-2)

Lowman BG, Scott NA \& Somerville SH 1976 Condition scoring of cattle. Bulletin, East of Scotland College of Agriculture 6 1-3.

Mamluk R, Chen D, Greber Y, Davis JS \& Meidan R 1998 Characterization of messenger ribonucleic acid expression for prostaglandin F2 alpha 
and luteinizing hormone receptors in various bovine luteal cell types. Biology of Reproduction 58 849-56. (doi:10.1095/biolreprod58.3.849)

McCarthy SD, Roche JF \& Forde N 2012 Temporal changes in endometrial gene expression and protein localization of members of the IGF family in cattle: effects of progesterone and pregnancy. Physiological Genomics 44 130-140. (doi:10.1152/physiolgenomics.00106.2011)

Minegishi T, Nakamura Y, Yamashita S \& Omori Y 2007 The effect of splice variant of the human luteinizing hormone $(\mathrm{LH})$ receptor on the expression of gonadotropin receptor. Molecular and Cellular Endocrinology 260262 117-125. (doi:10.1016/j.mce.2005.11.051)

Monget P, Pisselet C \& Monniaux D 1998 Expression of insulin-like growth factor binding protein- 5 by ovine granulosa cells is regulated by cell density and programmed cell death in vitro. Journal of Cellular Physiology 177 13-25. (doi:10.1002/(SICI)1097-4652(199810)177:1<13::AIDJCP2>3.0.CO; $2-\mathrm{H}$

Müller T, Gromoll J \& Simoni M 2003 Absence of exon 10 of the human luteinizing hormone $(\mathrm{LH})$ receptor impairs $\mathrm{LH}$, but not human chorionic gonadotrophin action. Journal of Clinical Endocrinology \& Metabolism 88 2242-2249. (doi:10.1210/jc.2002-021946)

Murdoch WJ \& Van Kirk EA 1998 Luteal dysfunction in ewes induced to ovulate early in the follicular phase. Endocrinology 139 3480-3484. (doi:10.1210/endo.139.8.6137)

Nakamura K, Yamashita S, Omori Y \& Minegishi T 2004 A splice variant of the human luteinizing hormone $(\mathrm{LH})$ receptor modulates expression of the wild-type human LH receptor. Molecular Endocrinology 181461 1470. (doi:10.1210/me.2003-0489)

Ndiaye K, Fayad T, Silversides DW, Sirois J \& Lussier JG 2005 Identification of downregulated messenger RNAs in bovine granulosa cells of dominant follicles following stimulation with human chorionic gonadotropin. Biology of Reproduction 73 324-333. (doi:10.1095/ biolreprod.104.038026)

Neuvians TP, Pfaffl MW, Berisha B \& Schams D 2003 The mRNA expression of the members of the IGF-system in bovine corpus luteum during induced luteolysis. Domestic Animal Endocrinology 25 359-372. (doi:10.1016/j.domaniend.2003.08.002)

Nio-Kobayashi J, Trendell J, Giakoumelou S, Boswell L, Nicol L, Kudo M, Sakuragi N, Iwanaga T \& Duncan WC 2015 Bone morphogenetic proteins are mediators of luteolysis in the human corpus luteum. Endocrinology 156 1494-503. (doi:10.1210/en.2014-1704)

Niswender GD, Davies TL, Griffith RJ, Bogan RL, Monser K, Bott RC, Bruemmer JE \& Nett TM 2007 Judge, jury and executioner: the autoregulation of luteal function. Reproduction in Domestic Ruminants VII; Society of Reproduction and Fertility 64 191-206.

Nogueira MFG, Buratini J Jr, Price CA, Castilho ACS, Pinto MGL \& Barros CM 2007 Expression of LH receptor mRNA splice variants in bovine granulosa cells: changes with follicle size and regulation by FSH in vitro. Molecular Reproduction and Development 74 680-686. (doi:10.1002/(ISSN)1098-2795)

O'Hara L, Scully S, Maillo V, Kelly AK, Duffy P, Carter F, Forde N, Rizos D \& Lonergan P 2012 Effect of follicular aspiration just before ovulation on corpus luteum characteristics, circulating progesterone concentrations and uterine receptivity in single-ovulating and superstimulated heifers. Reproduction 143 673-682. (doi:10.1530/REP-11-0505)

Okuda K, Korzekwa A, Shibaya M, Murakami S, Nishimura R, Tsubouchi M, Woclawek-Potocka I \& Skarzynski DJ 2004 Progesterone is a suppressor of apoptosis in bovine luteal cells. Biology of Reproduction 712065 2071. (doi:10.1095/biolreprod.104.028076)

Perry GA, Smith MF, Lucy MC, Green JA, Parks TE, MacNeil MD, Roberts AJ \& Geary TW 2005 Relationship between follicle size at insemination and pregnancy success. PNAS 102 5268-5273. (doi:10.1073/pnas.0501700102)

Pursley JR, Mee MO \& Wiltbank MC 1995 Synchronization of ovulation in dairy cows using PGF2 $\alpha$ and GnRH. Theriogenology 44 915-923. (doi:10.1016/0093-691X(95)00279-H)

Quintal-Franco JA, Kojima FN, Melvin EJ, Lindsey BR, Zanella E, Fike KE, Wehrman ME, Clopton DT \& Kinder JE 1999 Corpus luteum development and function in cattle with episodic release of luteinizing hormone pulses inhibited in the follicular and early luteal phases of the estrous cycle. Biology of Reproduction 61 921-926. (doi:10.1095/ biolreprod61.4.921)

Rai AJ, Kamath RM, Gerald W \& Fleisher M 2009 Analytical validation of the GeXP analyzer and design of a workflow for cancer-biomarker discovery using multiplexed gene-expression profiling. Analytical and Bioanalytical Chemistry 393 1505-1511. (doi:10.1007/s00216-0082436-7)

Reiner A, Yekutieli D \& Benjamini Y 2003 Identifying differentially expressed genes using false discovery rate controlling procedures. Bioinformatics 19 368-375. (doi:10.1093/bioinformatics/btf877)

Robinson RS, Nicklin LT, Hammond AJ, Schams D, Hunter MG \& Mann GE 2007 FGF2 is more dynamic than VEGFA during the follicle-luteal transition in the cow. Biology of Reproduction 77 28-36. (doi:10.1095/ biolreprod.106.055434)

Robert C, Gagné D, Lussier JG, Bosquet D, Barnes FL \& Sirard MA 2003 Presence of LH receptor mRNA in granulosa cells as a potential marker of oocyte developmental competence and characterization of bovine splicing isoforms. Reproduction 125 437-446. (doi:10.1530/ rep.0.1250437)

Savio JD, Keenan L, Boland MP \& Roche JF 1988 Pattern of growth of dominant follicles during the oestrous cycle in heifers Journal of Reproduction and Fertility 83 663-671. (doi:10.1530/ jrf.0.0830663)

Sharma SC, Clemens JW, Pisarska MD \& Richards JS 1999 Expression and function of estrogen receptor subtypes in granulosa cells: regulation by estradiol and forskolin. Endocrinology 140 4320-4334.

Skarzynski DJ \& Okuda K 1999 Sensitivity of bovine corpora lutea to prostaglandin F2a is dependent on progesterone, oxytocin, and prostaglandins. Biology of Reproduction 60 1292-1298. (doi:10.1095/ biolreprod60.6.1292)

Webb R \& Campbell BK 2007 Development of the dominant follicle: mechanisms of selection and maintenance of oocyte quality. Society of Reproduction and Fertility Supplement 64 141-163.

Wiltbank MC, Souza AH, Carvalho PD, Bender RW \& Nascimento AB 2011 Improving fertility to timed artificial insemination by manipulation of circulating progesterone concentrations in lactating dairy cattle. Reproduction, Fertility and Development 24 238-243. (doi:10.1071/ RD11913)

Wiltbank MC \& Pursley JR 2014 The cow as an induced ovulator: timed Al after synchronization of ovulation. Theriogenology 81 170-185. (doi:10.1016/j.theriogenology.2013.09.017)

Wonnacott KE, Kwong WY, Hughes J, Salter AM, Lea RG, Garnsworthy PC \& Sinclair KD 2010 Dietary omega-3 and -6 polyunsaturated fatty acids affect the composition and development of sheep granulosa cells, oocytes and embryos. Reproduction 139 57-69. (doi:10.1530/REP-090219)

Wu Y, Gutierrez MR, Sciabica KE \& Luo J 2008 Quantitative multiplexed gene expression: an analysis of sensitivity, accuracy and precision. Technical Information Bulletin, B2008-8704, Beckman Coulter Inc.

Yoshioka S, Abe H, Sakumoto R \& Okuda K 2013 Proliferation of luteal steroidogenic cells in cattle. PLOS ONE 8 e84186. (doi:10.1371/journal. pone.0084186)

Yuan W \& Lucy MC 1996 Messenger ribonucleic acid expression for growth hormone receptor, luteinizing hormone receptor, and steroidogenic enzymes during the estrous cycle and pregnancy in porcine and bovine corpora lutea. Domestic Animal Endocrinology 13 431-444. (doi:10.1016/0739-7240(96)00073-2)

Received 8 September 2015

First decision 29 October 2015

Revised manuscript received 16 February 2016

Accepted 3 March 2016 